\title{
СИНТЕЗ И ОЦЕНКА АНТИОКСИДАНТНОЙ СПОСОБНОСТИ ПРОИЗВОДНЫХ 2,6-ДИИЗОБОРНИЛФЕНОЛА С АМИНОМЕТИЛЬНОЙ ГРУППОЙ В ПОЛОЖЕНИИ 4
}

\author{
О.Г. Шевченко', Е.В. Буравлёв², А.В. Кучин ${ }^{2}$ \\ ${ }^{1}$ Институт биологии Коми научного центра Уральского отделения \\ Российской академии наук, 167982, Россия, Сыктывкар, ул. Коммунистическая, 28. \\ ${ }^{2}$ Институт химии Коми научного центра Уральского отделения Российской академии \\ наук, 167000, Россия, Сыктывкар, ул. Первомайская, 48.
}

DOI: 10.19163/MedChemRussia2021-2021-548

E-mail: microtus69@mail.ru

На основе 2,6-диизоборнил-4-метилфенола (1) синтезированы производные 2-5, содержащие в пара-положении относительно гидроксигруппы соответственно (фениламино)метильный, (бензиламино)метильный, (2-бензил$1 H$-бензо[d]имидазол-1-ил)-метильный или $\quad(1 \mathrm{H}$-бензо[d][1,2,3]триазол-1-ил) метильный фрагмент. На моделях in vitro проведена оценка антирадикальной активности в тесте с DPPH, антиоксидантной активности (AOA) на субстратах, содержащих животные липиды (гомогенаты головного мозга и семенников лабораторных мышей), исследованы гемолитическая активность, АОА и мембранопротекторные свойства с использованием эритроцитов крови мышей.

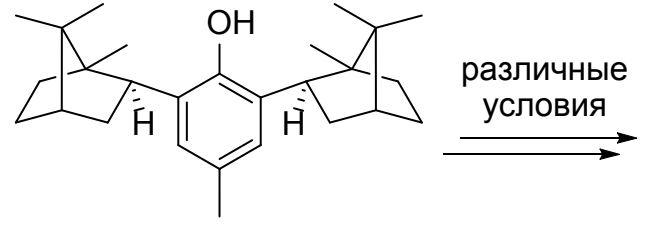

1<smiles>[R2]NCc1cc([C@H]2C[C@@H]3CC[C@](C)(C2)C3(C)C)c(O)c([C@@H]2C[C@@H]3CC[C@](C)(C2)C3(C)C)c1</smiles>

2-5

$\mathrm{NR}^{1} \mathrm{R}^{2}=\mathrm{NHPh}(\mathbf{2}), \operatorname{NHBn}(\mathbf{3}), \sum_{X=N}(X=\mathrm{CBn}(\mathbf{4}), \mathrm{N}(\mathbf{5}))$

Показано, что АОА зависит от структуры заместителя, находящегося в naра-положении относительно фенольной ОН-группы, а также от используемой тест-системы и в ряде случаев может быть связана с мембраностабилизирующим действием соединений. В тесте с DPPH лидировали вторичные амины 2 и 3, в то время как по способности защищать эритроциты в условиях ААРН-индуцированного окислительного стресса наибольшую активность проявило производное 5.

Результаты исследования представлены в работе [1].

\section{Литература}

[1] Е.В. Буравлев, О.Г. Шевченко, А.В. Кучин, Изв. АН. Сер. хим. 2021, 183-190. 